\title{
THE USE OF ER:YAG LASER FOR DENTAL CARIES REMOVAL
}

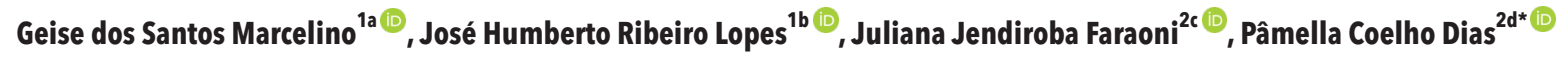 \\ 'School of Dentistry, Faculdade Morgana Potrich (FAMP), Mineiros, Goiás, Brazil \\ ${ }^{2}$ Restorative Dentistry Department, School of Dentistry, University of São Paulo (USP), Ribeirão Preto, São Paulo, Brazil \\ aDDS, General Dentist; email: hisy74@gmail.com; ORCID-iD: https://orcid.org/0000-0003-0056-1580 \\ bDSS, General Dentist; email: zehumbert096@gmail.com; ORCID-iD: https://orcid.org/0000-0001-5028-4425 \\ 'DDS, PhD, Researcher; email: jujfaraoni@yahoo.com.br; ORCID-iD: https://orcid.org/0000-0003-0945-4028 \\ dDDS, MSc, PhD student; email: pamellacdias@hotmail.com; ORCID-iD: https://orcid.org/0000-0003-4886-3940
}

\begin{abstract}
di) https://doi.org/10.25241/stomaeduj.2021.8(3).art.3
\end{abstract}

Background Carious tissue removal in enamel and dentin requires the use of sharp and resistant instruments. New tools have appeared to optimize/facilitate dental treatment, among them the laser. Regarding laser application for dental caries removal, the use of erbium laser doped with yttrium, aluminum, and garnet (Er:YAG) stands out. The Er:YAG laser is excellent for hard tissues ablation since its wavelength of 2.940nm is highly absorbed by water and hydroxyapatite.

Objective To review the application of the Er:YAG laser in dental caries removal, to present its advantages and limitations in clinical practice, as well as to describe its action mechanism, and to compare its effectiveness with different methods used to remove caries.

Data sources The search for articles to compose this literature review was carried out in the PubMed and Embase databases.

Study selection Articles in English published between 2006 and 2021. The manual search included additional articles and books; a total of 39 references were selected.

Data extraction Information from studies that evaluated the use of the Er:YAG laser to remove caries or related this type of laser to other methods. Articles that evaluated characteristics of the dental structure, or the influence of restorative materials after caries removal with the Er:YAG laser, were also considered.

Study selection Based on studies results, the Er:YAG laser presents itself as an alternative for caries removal since it can remove demineralized tissue (selective ablation) without causing damage to the dental element.

\section{KEYWORDS}

Cariology; Dental Caries; Dental Caries Removal; Dentin; Lasers.

\section{INTRODUCTION}

Contemporary dentistry is based on early diagnosis, adequacy of the oral environment, and prevention of oral diseases. In recent years, new tools have emerged to optimize/facilitate dental treatment, including laser. Studies carried out over the years have proven the effectiveness of laser therapy for hard and soft tissues manipulation [1-3].

The word LASER comes from the English acronym Light Amplification by Stimulated Emission of Radiation. Its mechanism of action is based on the emission of a collimated light beam of high energy intensity and can be stimulated by solid, liquid, or gaseous active medium. Lasers have different wavelengths, and this implies the variable phenomena that they can present: absorption, penetration, transmission, and diffusion. In dentistry, the most desirable phenomenon is absorption, as it will interact with living tissue, effectively exercising its different functions [4].
Lasers can be classified, according to their application, in low and high-power lasers [4]. Lowpower lasers can aid analgesia, reduce inflammation and stimulate tissue repair [3,5], while high-powered ones are used in surgery, ablation of decayed tissue, and orthodontics $[2,4,5]$. There are also lasers used for photodynamic therapy and tissue fluorescence diagnosis [4].

Regarding the application of laser for dental caries removal, the use of erbium-doped yttrium, aluminum, and garnet laser (Er:YAG laser) stands out. This laser operates in a pulsed mode, and the handpiece includes a spray of water to prevent tissue dryness and heat build-up, allowing energy to be absorbed efficiently [6].

Several types of research have evaluated the use of lasers in dentistry, highlighting the erbium laser in hard tissues $[1,2,7,8]$. This study aimed to perform a literature review about the application of the Er:YAG laser in dental caries removal and to present its advantages and limitations in clinical practice.

(c) (1) \&) OPEN ACCESS This is an Open Access article under the CC BY-NC 4.0 license

(c) (1) () OPEN ACCESS This is an

Citation: Marcelino GDS, Lopes JHR, Faraoni JJ, Dias PC. The use of Er:YAG laser for dental caries removal. Stoma Edu J. 2021;8(3):173-183. Received: August 17, 2021; Revised: September 11, 2021; Accepted: September 27, 2021; Published: September 28, 2021

*Corresponding author: Pâmella Coelho Dias, DDS, MSc, PhD student; Department of Restorative Dentistry, School of Dentistry, University of São

Paulo, Avenida do Café, s/n, 14040-904, Ribeirão Preto, SP, Brazil; Tel./Fax: +55 16 3315-4016; e-mail: pamellacdias@hotmail.com

Copyright: $\odot 2021$ the Editorial Council for the Stomatology Edu Journal. 


\section{METHODOLOGY}

The article search for this literature review utilized the PubMed and Embase databases, and the selection included articles published between 2006 and 2021. The terms used were "Er:YAG laser" AND "dental caries removal". The inclusion criteria included articles in English published between 2006 and 2021 that evaluated the use of the Er:YAG laser to remove caries or related this type of laser to other methods. Articles that evaluated characteristics of the dental structure, or the influence of restorative materials after removal of caries with Er:YAG laser, were also considered. The search excluded: literature reviews, monographs, case reports, studies with bovine teeth, and studies with artificial or induced demineralization. The manual search included ten studies: three books, four original articles, and three reviews as they contained viable information to structure this literature review. Figure 1 shows the flowchart detailing the selection of articles. In total, this review included 39 references.

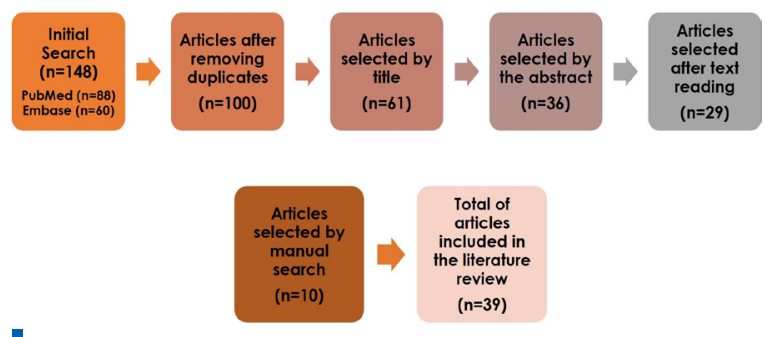

Figure 1. Flowchart of the article selection process.

\section{LITERATURE REVIEW}

Dental caries is described in the literature as a multifactorial disease influenced by genetic, environmental, and behavioral characteristics, being a complex disease resulting from the accumulation of specific acidogenic bacterial colonies present in the dental biofilm, capable of adhering to the tooth. These, in turn, produce acids from their metabolism using fermentable carbohydrates responsible for decreasing the $\mathrm{pH}$ on the dental surface, promoting the reduction of hydroxyapatite crystals and the widening of the intercrystalline spaces, leading to an increase in porosity and, consequently, the emergence of the disease [9].

Clinically, the active initial caries lesion appears on enamel as a white spot with a rough and opaque appearance. With the progression of demineralization, this lesion forms a cavity that can progress to reach the dentin, which then starts to show generally a yellow color, moist aspect, and softened consistency [9].

The removal of decayed enamel and dentin tissue requires the use of strong and sharp instruments to allow the proper preparation of the cavity. There are several instruments used for cavity preparation, such as hand instruments (chisels, dentin scoop) and rotary instruments (carbide burs with different types of active tip, diamond tips) [10]. Previous studies have shown that chemical-mechanical methods like Carisolv ${ }^{\circledR}$ and Papacarie $^{\circledR}$ are also effective in removing caries $[11,12]$.

The laser is another alternative that has been used in the dental field as an effective method for removing decayed tissue, being considered a conservative method since such removal is selective. Besides, laser treatment promotes greater comfort during the surgical procedure and without causing pulpal damage [13-15]. The type of laser most used for this purpose is the yttrium-aluminum-garnet erbium laser (Er:YAG).

The Er:YAG laser is excellent for the ablation of hard tissues, as it has a wavelength of $2.940 \mathrm{~nm}$, which is highly absorbed in water and hydroxyapatite. The erbium laser creates microexplosions in the hydroxyapatite by vaporizing the water molecules present in the hard tissues, which leads to the breakdown of this tissue during the ablation process. This laser operates in a pulsed mode, and the handpiece includes a spray of water to prevent tissue dryness and heat accumulation, allowing the energy to be absorbed efficiently. Thus, its action occurs without tissue carbonization and with minimal generation of heat [6]. Its use was approved for these purposes by the Food and Drug Administration (FDA) in May 1997 [14].

Research that used scanning electron microscopy (SEM) and thermographic study to evaluate the pulp temperature during the use of Er:YAG laser in deciduous and permanent teeth showed that in the same pulse of energy, ablation in dentin was more effective than in enamel and that ablation and caries removal values were significantly higher in primary teeth when comparing to permanent teeth, but without exceeding the temperature of $5.5^{\circ} \mathrm{C}$ [7].

Eberhard et al. (2008) analyzed extracted decayed permanent molars in which they were sectioned and treated with fluorescence-feedback controlled (FFC) Er:YAG laser or diamond tips. The use of the FCC Er:YAG laser at a threshold of $7 U$ (units) resulted in less dentin loss when compared to the use of diamond tips [16].

A randomized clinical trial compared the efficacy of the fluorescence-controlled Er:YAG laser and the low-speed bur in removing decayed tissue in adults. The results showed that the use of the FCC laser at a threshold of 7 and $8 \mathrm{U}$ promotes the same effectiveness of the bur, presenting insignificant numbers of remaining bacteria [17].

One research evaluated different techniques for caries removal and found no selectivity for demineralized tissue using the Er:YAG laser. In this study, the laser showed significant variability in the results, where several samples remained with amounts of remaining caries and others had tooth structure removed in excess [18].

A study evaluating the rate of ablation and selectivity of healthy and demineralized enamel and dentin promoted by a 30W (watts) diode-pumped Er:YAG

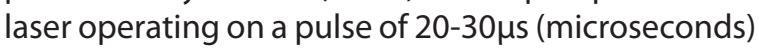


showed that this laser has considerable potential for selective removal of dental caries [19].

Analysis of the removal of demineralized dentin using the FFC Er:YAG laser showed that dentin ablation occurred effectively at fluorescence control values between $6 \mathrm{U}$ and $7 \mathrm{U}$ when measured by microCT (computed microtomography). While at a value greater than $8 \mathrm{U}$, the removal of decayed dentin was unsatisfactory [20].

Kornblit et al. (2008) evaluated the effectiveness of the Er:YAG laser in removing caries in deciduous and permanent molars and observed that ablation in areas infected by caries promoted maximum maintenance of the remaining structure. According to these authors, the laser provided decontamination of the affected area and improved retention of the composite resin to the surface prepared with laser, promoting better marginal enamel sealing [2].

Yonemoto et al. (2006) evaluated the DIAGNOdent ${ }^{\circledR}$ as a guide for caries removal using the Er:YAG laser. Values set at 11-20 were able to remove caries preserving the affected dentin in vitro [21].

An in vivo study used 120 primary teeth from children aged 5 to 9 years, divided into four groups: air rotor, Carisolv ${ }^{\circledR}$, Papacarie $^{\circledR}$, and Er:YAG laser. The results were visually and tactile observed, besides having the values of the DIAGNOdent ${ }^{\circledR}$ pen and the FLACC scale (Face, Legs, Activity, Cry, Consolability) to measure pain during the procedure. Air rotor and laser were the most effective and efficient methods, and laser and chemical-mechanical methods were considered more comfortable [13].

Another in vivo study evaluated the FFC Er:YAG laser for caries removal in pediatric patients. S. mutans and or Lactobacilli were found in $33.33 \%$ of the lesions. In a total of 79 lesions, 14 contained S. mutans and 15 contained Lactobacilli. The average log of colonyforming units (CFU) per sample was 0 for S. mutans and Lactobacilli. The average time to perform the procedure was $2.3 \pm 1.2 \mathrm{~min}$. Regarding pain, $93.8 \%$ of children considered laser usage comfortable [15]. One research biochemically analyzed decayed and healthy teeth treated by the fluorescence-controlled Er:YAG laser, where a layer of dentin was removed from the bottom of the preparation to determine the presence of hydroxylysylpyridinoline (HP) and lysylpyridinoline (LP) collagen cross-links using high-performance liquid chromatography. 100\% HP and LP were found in decayed dentin and $0.33 \%$ HP and $0.68 \%$ LP in healthy dentin. After caries removal, $0.84 \% \mathrm{HP}$ and $1.26 \% \mathrm{LP}$ were found at the $5 \mathrm{U}$ fluorescence-control threshold and $1.56 \% \mathrm{HP}$ and $2.48 \% \mathrm{LP}$ at $10 \mathrm{U}$. The Er:YAG laser proved to be a viable method for removing the irreversibly denatured collagen present in decayed dentin [1]. Scanning electron microscope was used to investigate the morphological changes in the hard dental tissues after caries removal and cavity preparation using different methods: Er:YAG laser, Carisolv $^{\circledR}$ gel, high-speed diamond burs, and lowspeed micromotor steel burs. The dental surface after using the laser remained highly retentive, without smear layer residues and with the presence of exposed dentinal tubules. The samples treated with Carisolv $^{\circledR}$ gel presented a rough retentive surface and some dentinal tubules obliterated by denatured collagen and surface contaminants; surfaces prepared with low and high-speed burs showed a thick smear layer and no micro retentions [22].

An in vitro study evaluated marginal microleakage of cavities restored with glass ionomer, comparing Er:YAG laser with Apacaries gel and atraumatic restorative technique (ART), and found a higher level of infiltration with the use of the laser to remove caries compared to the other methods [23].

Studies show that different techniques for removing decayed tissue influence the bond strength of adhesive systems [24-27]. The study of Yildiz et al. (2013) concluded that the chemical-mechanical method or use of burs at low rotation compared to the Er:YAG laser show better results in terms of bond strength for both self-etch and total-etch adhesives [27]. In another study, using a 2-step selfetch adhesive system, the dentin surface prepared by the Er:YAG laser showed lower micro-tensile bond strength ( $\mu \mathrm{TBS})$ values compared to healthy dentin [24]. In the study of Sattabanasuk et al. (2006), the bond strength values of a total-etch adhesive system were similar for the Er:YAG laser and steel bur [25].

Sirin Karaarslan et al. (2012) evaluated the microtensile bond strength of 3 types of adhesive systems - Clearfil ${ }^{\otimes}$ SE Bond (2-step self-etch), G-Bond ${ }^{\circledR}$ (singlestep self-etch), and Adper ${ }^{\circledR}$ Single Bond 2 (2-step total-etch) after caries removal using a spherical steel bur at low-speed, Carisolv ${ }^{\circledR}$ gel or the Er:YAG laser. Based on the results, the techniques used to remove decayed tissue showed significant differences in bond strength between the adhesive systems. There was no significant difference in the bond strength of total-etch adhesive systems comparing laser and bur groups. Using the laser, Adper ${ }^{\oplus}$ Single Bond 2 was superior to the other adhesive systems, indicating that total-etch adhesives are the best option in this type of caries removal method [26].

The microhardness and chemical composition of dentin vary according to the applied caries removal method. The chemical-mechanical technique $\left(\right.$ Carisolv $\left.^{\circledR}\right)$ showed lower microhardness of the remaining dentin and a considerable number of samples with residual caries (20\%) when compared to the carbide bur and the Er:YAG laser (both 5\%). There was no significant difference in calcium and phosphorus rates of the three evaluated groups [28]. A comparative clinical study between the bur and the Er:YAG laser to remove caries from primary molars showed that the laser was less efficient than the bur to remove caries. Regarding effectiveness, the two treatments were similar to remove caries in the pulp wall, and the bur was better in the surrounding walls. The composite resin restorations for both groups remained satisfactory after one year of treatment [8]. A double-blind clinical study, performed in children aged 7-10 years, evaluated composite resin restorations in primary teeth performed after selective removal of necrotic dentin using an Er:YAG laser and a carbide bur. Adhesive restorations did not suffer laser interference, and the SEM analysis showed that laser group restorations showed a $10 \%$ gap in its extension, and the group treated with a bur showed 
a $20 \%$ gap in the cavosurface margin after 12 months of follow-up [29].

A longitudinal clinical study with four years of follow-up evaluated the clinical longevity of composite resin restorations after selective caries removal in permanent molars using the Er:YAG laser or bur preparation with chlorhexidine as dentin biomodifier. The Er:YAG laser group biomodified with chlorhexidine presented a statistically significant difference for marginal adaptation criteria compared to the other groups; for secondary caries criteria and clinical and radiographic evaluation of pulp vitality, there was no statistically significant difference between the evaluated groups. The authors concluded that the method of caries removal and dentin biomodification did not influence the survival rate of composite resin restorations [30].

Prabhakar et al. (2018) evaluated morphological changes and the presence of bacterial deposits in primary decayed molars submitted to carious tissue removal by Carie-Care (chemical-mechanical method), Er:YAG laser, and tungsten carbide spherical bur. The results showed that the laser group was the most effective of the three, with fewer bacterial deposits and no smear layer formation [31]. A meta-analysis evaluated the Er:YAG laser to remove caries and for cavity preparation in children compared to the traditional mechanical method. This study evaluated seven randomized clinical trials and found that the laser requires more operative time but is less painful. There were no statistically significant differences between the two types of treatment concerning retention, marginal adaptation, and marginal discoloration of restorations [32].

$A$ recent systematic review showed that the use of burs, chemomechanical method, and the Er:YAG laser are efficient for caries removal, reduction of bacteria in the tooth cavity, and do not compromise the clinical performance of restorations [33].

An in vitro study compared the FFC Er:YAG laser with the Er:YAG laser in three different pulses (super short, medium short, and short pulse) regarding the efficiency of removing cariogenic bacteria and carious dentin and dentin temperature during ablation. The results showed that no experimental group had bacterial contamination after treatment. In the groups with varied pulses of laser energy, the dentin temperature was significantly higher than the FFC laser [34].

A study that evaluated and compared the Er:YAG laser, the tungsten bur, and the polymer bur in caries removal showed no difference between the treatment time comparing the three methods. Histological analysis showed that all groups effectively removed the infected dentin and the laser group showed a regular $5 \mu \mathrm{m}$ thick layer of denatured collagen. The group treated by the tungsten bur presented a smear layer, and the polymer bur group showed an affected dentin surface layer [35].

Matsumoto et al. (2007) clinically evaluated the applicability of the Er:YAG laser on 95 decayed teeth from 45 patients. No adverse reactions and no or little pain were reported in most treated teeth (89.5\%). Tooth preparation was successfully performed exclusively by laser in $94.7 \%$ of the cases, and the operative time was on average 49 seconds [36].

\section{DISCUSSION}

The Er:YAG laser to remove caries has been widely studied in recent years, showing that it is a safe and comfortable method for the patient, minimizing the use of local anesthesia and maintaining pulp vitality $[2,7,13,17]$.

Studies comparing different methods of caries removal found that the Er:YAG laser, together with the chemical-mechanical method, provided greater comfort and satisfaction for both the operator and the patient as they were less traumatic [13]. According to a systematic review, chemomechanical methods are the best option for a minimally invasive treatment [33]. In an in vitro study, the hand excavator was the most effective technique to remove caries in deciduous teeth [37].

Comparing caries removal effectiveness (capacity) between laser and carbide bur at low rotation, the results of the two methods were similar for removing caries from the pulpal wall; the bur was more effective on the surrounding walls of primary molars [8]. Both techniques showed similar results regarding the presence of residual caries [28].

The adjusted value in lasers with fluorescencefeedback control influenced selectivity for carious tissue in the studies evaluated in this literature review. Schwass et al. (2013) showed that the Er:YAG laser with fluorescence control selected between $7 \mathrm{U}$ and $8 \mathrm{U}$ was effective for removing demineralized dentin [20], as well as studies by Dommisch et al. (2008) [17] and Eberhard et al. (2008) [16], where the Er:YAG laser with fluorescence control at levels of $7 \mathrm{U}$ and $8 \mathrm{U}$ promoted caries removal similar to that obtained with the conventional bur, generating greater comfort and wellness to the patient. The use of a laser with fluorescence control set to $9 \mathrm{U}$ and $10 \mathrm{U}$ did not remove all decayed tissue [17]. Contrasting these results, Neves et al. (2011) did not find selectivity when analyzing samples prepared with the FFC Er:YAG laser at the threshold of $7 \mathrm{U}$, where some specimens were overprepared, and others continued with decayed tissue. In this study, the laser was the evaluated method that presented the least minimally invasive potential [18].

Regarding the morphological changes generated on the treated dental surface, the laser did not promote thermal damage and also left the surface highly retentive and without the presence of a smear layer; while the use of burs in both high and low rotation promoted surfaces with a thick smear layer and absence of microretentions; the use of polymer burs left an affected dentin layer [22,35].

Despite the advantages of using laser as a method of removing decayed tissue, clinical studies have 
shown variation in clinical time, with laser consuming about $3 x$ more time than the use of burs [17] with an average treatment duration of $2.3 \pm 1.2 \mathrm{~min}$ [15]. Other studies have also shown a longer average treatment time with the use of laser, but with a minor difference: 110s [8] or 49s [36] for the Er:YAG laser and 55s [8] for the low-speed carbide bur. Another disadvantage found in one of the selected studies was the presence of marginal infiltration in decayed teeth ablated by laser and restored with glass ionomer [23].

The bond strength of adhesive systems influenced the method used to remove caries [26]. According to the results, the authors suggest choosing a conventional adhesive system after caries removal by the Er:YAG laser and a self-etch adhesive system after using a chemical-mechanical method. These results corroborate the study by Neves et al. (2011) that found lower micro-tensile bond strength using a 2-step self-etch adhesive after caries removal by the Er:YAG laser compared to the chemical-mechanical method and the use of conventional burs [24]. In another study, the use of a chemical-mechanical technique or usage of burs at low-speed compared to Er:YAG laser showed better results in terms of bond strength for both self-etch and total-etch adhesive systems [27]. Other studies showed that the Er:YAG does not influence the bond strength value of a total-etch adhesive system $[25,38]$; however, the study of Sattabanasuk et al. (2006) showed higher bond strength values for Er:YAG laser compared to steel bur evaluating a self-etch adhesive system (Clearfil Protect Bond) [25].
A 12-month follow-up of a randomized clinical trial with a split-mouth design showed that teeth with decayed tissue removed by both laser and bur and restored with a 2-step total-etch adhesive system and composite resin maintained satisfactory restorative treatment [8]. In a double-blind clinical study, the restorations of the laser group showed a lower percentage of a gap than the group treated by bur in the analysis performed by SEM at the same follow-up time [29].

In a biochemical analysis of dentin collagen on decayed surfaces treated with erbium laser through SEM, the percentage of dehydrated collagen and decayed dentin reduced after laser treatment, becoming similar to healthy dentin [1]. In the study of Krause et al. (2008), 42.9\% of the samples had bacterial residues, but in only $7.1 \%$, the bacterial count was greater than 100 CFU (colony forming units) [15].

The pulp response to the application of external heat was evaluated in an in vivo study using rhesus monkeys [39]. The results showed that a temperature increase of $2.2^{\circ} \mathrm{C}$ does not cause pulp changes and that increase of $5.5^{\circ} \mathrm{C}$ allowed pulp repair for most specimens (75\%). In several studies, the use of the Er:YAG laser has proven not to generate thermal damage to the dental structure, not exceeding the temperature increase above the threshold tolerated by the dental pulp $[2,7,19,34]$.

Table 1 summarizes the 29 studies selected by Pubmed and Embase.

\begin{tabular}{|c|c|c|c|c|c|}
\hline Author (Year) & Substrate & $\begin{array}{l}\text { Type of } \\
\text { study }\end{array}$ & $\begin{array}{c}\text { Evaluated } \\
\text { parameters }\end{array}$ & $\begin{array}{l}\text { Er:YAG laser } \\
\text { specifications }\end{array}$ & Conclusion \\
\hline $\begin{array}{l}\text { Al-Batayneh et } \\
\text { al. (2014) [7] }\end{array}$ & $\begin{array}{l}\text { Sound and carious } \\
\text { enamel and dentin } \\
\text { from } 40 \text { primary e } \\
40 \text { permanent } \\
\text { extracted teeth }\end{array}$ & $\begin{array}{l}\text { In vitro } \\
\text { comparative } \\
\text { study }\end{array}$ & $\begin{array}{l}\text { - Laser ablation in } \\
\text { sound enamel and } \\
\text { dentin } \\
\text { - Comparison } \\
\text { between the Er:YAG } \\
\text { laser and the rotary } \\
\text { bur for carious } \\
\text { removal } \\
\text { - Surfaces changes } \\
\text { through SEM }\end{array}$ & $\begin{array}{l}\text { - Wavelength: } 2.94 \mu \mathrm{m} \\
\text { - Pulse energy: } 200 \mathrm{~mJ} \\
\text { - Pulse duration: } 250 \mu \mathrm{s} \\
\text { - Frequency: } 10 \mathrm{~Hz} \\
\text { - Power output: } 6 \mathrm{~W}\end{array}$ & $\begin{array}{l}\text { - Laser creates greater crater } \\
\text { depths in dentin than enamel } \\
\text { for both types of teeth } \\
\text { - Laser is more efficient than } \\
\text { the rotary bur to remove } \\
\text { caries in primary teeth } \\
\text { - There was no significant } \\
\text { difference between } \\
\text { both methods regarding } \\
\text { permanent teeth } \\
\text { - Dental ablation did not } \\
\text { exceed } 5.5^{\circ} \mathrm{C} \\
\text { - SEM: dentin ablation with } \\
\text { no smear layer }\end{array}$ \\
\hline $\begin{array}{l}\text { Baraba et al. } \\
\text { (2018) [34] }\end{array}$ & $\begin{array}{l}60 \text { teeth with } \\
\text { dentin caries and } \\
12 \text { teeth without } \\
\text { caries lesion. }\end{array}$ & $\begin{array}{l}\text { In vitro } \\
\text { comparative } \\
\text { study }\end{array}$ & $\begin{array}{l}\text { Caries removal } \\
\text { efficiency of the FFC } \\
\text { Er:YAG laser and } \\
\text { different pulses of } \\
\text { the Er:YAG laser } \\
\text {-PCR analysis } \\
\text {-Thermal alterations }\end{array}$ & $\begin{array}{l}\text { FCC laser: } \\
\text {-Pulse energy: } 350 \mathrm{~mJ} \\
\text { (enamel) and } 250 \mathrm{~mJ} \\
\text { (dentin) } \\
\text {-Pulse duration: } 400 \mu \mathrm{s} \\
\text {-Frequency: } 4 \mathrm{~Hz} \\
\text {-Threshold: } 7 \mathrm{U} \\
\text { Laser with different } \\
\text { pulses: } \\
\text {-Pulses: } 50 \mu \mathrm{s}, 100 \mu \mathrm{s}, \\
\text { and } 300 \mu \mathrm{s} \\
\text {-Pulse energy: } 350 \mathrm{~mJ} \\
\text { (enamel) and } 250 \mathrm{~mJ} \\
\text { (dentin) } \\
\text {-Frequency: } 10 \mathrm{~Hz} \\
\text {-Non-contact mode } \\
\text {-Distance: } 7 \mathrm{~mm}\end{array}$ & $\begin{array}{l}\text {-Ablated specimens were } \\
\text { bacteria-free } \\
\text {-All laser evaluated were } \\
\text { efficient for caries removal } \\
\text {-FCC laser group presented } \\
\text { the lowest average } \\
\text { temperature }\end{array}$ \\
\hline
\end{tabular}




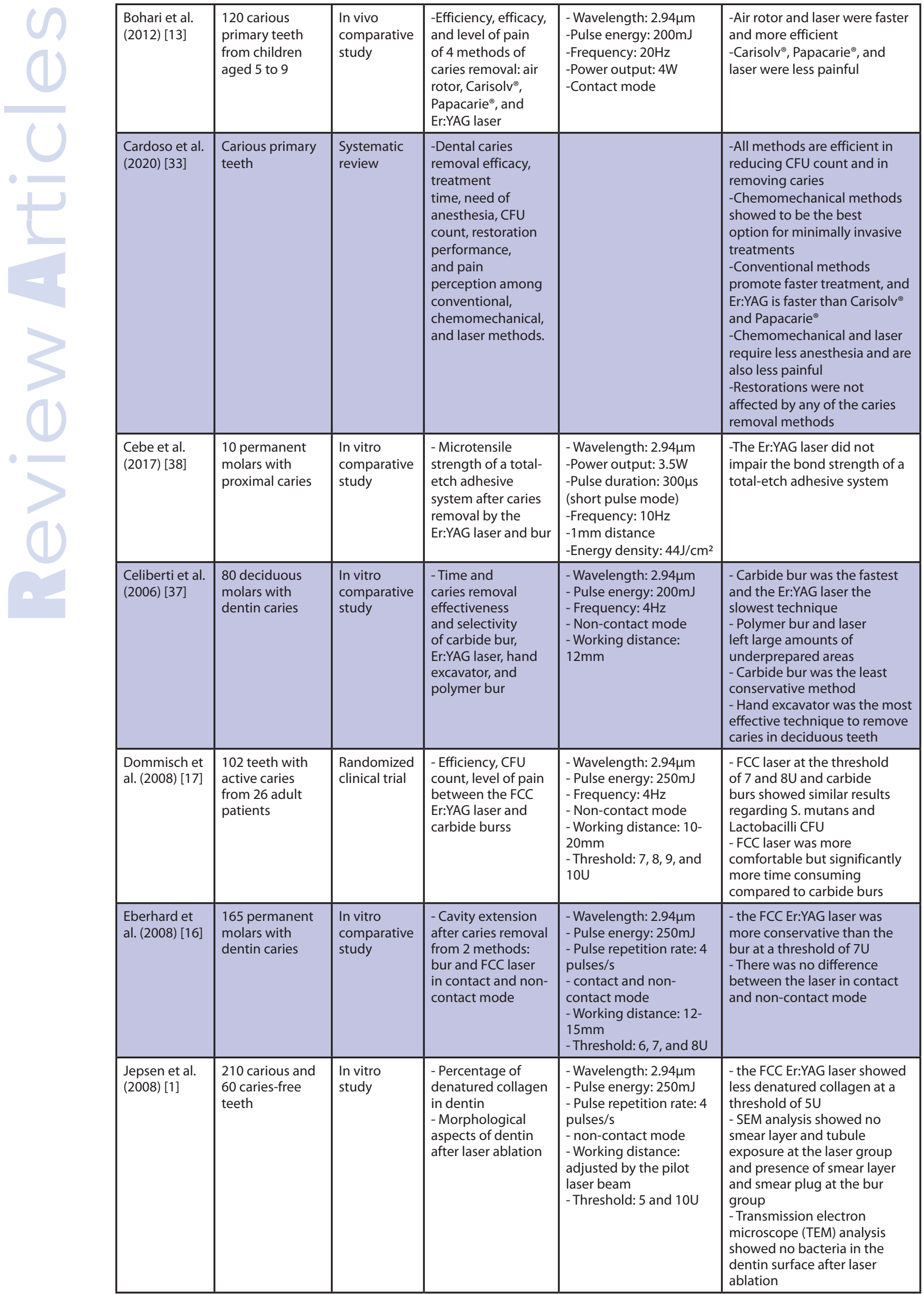




\begin{tabular}{|c|c|c|c|c|c|}
\hline $\begin{array}{l}\text { Juntavee } \\
\text { et al. (2013) } \\
{[23]}\end{array}$ & $\begin{array}{l}\text { Primary second } \\
\text { molars with } \\
\text { occlusal caries }\end{array}$ & $\begin{array}{l}\text { In vitro } \\
\text { comparative } \\
\text { study }\end{array}$ & $\begin{array}{l}\text { - Influence of } \\
\text { Apacaries gel, } \\
\text { Er:YAG laser, and } \\
\text { spoon excavator } \\
\text { as caries removal } \\
\text { methods in } \\
\text { the marginal } \\
\text { microleakage of } \\
\text { glass ionomer } \\
\text { restorations } \\
\end{array}$ & $\begin{array}{l}\text { - Pulse energy: } 260 \mathrm{~mJ} \\
\text { - Frequency: } 30 \mathrm{~Hz} \\
\text { - Pulse mode }\end{array}$ & $\begin{array}{l}\text { - the Er:YAG laser promoted } \\
\text { significant higher microleakage } \\
\text { than Apacaries and spoon } \\
\text { excavator in ionomer } \\
\text { restorations }\end{array}$ \\
\hline $\begin{array}{l}\text { Katirci et al. } \\
\text { (2016) [28] }\end{array}$ & $\begin{array}{l}\text { Permanent molars } \\
\text { with occlusal } \\
\text { caries }\end{array}$ & $\begin{array}{l}\text { In vitro } \\
\text { comparative } \\
\text { study }\end{array}$ & $\begin{array}{l}\text { - Effectiveness } \\
\text { of three caries } \\
\text { removal methods by } \\
\text { stereomicroscopic } \\
\text { observations and } \\
\text { microindentation } \\
\text { hardness } \\
\text { measurement } \\
\text { - Chemical } \\
\text { composition of the } \\
\text { residual dentin }\end{array}$ & $\begin{array}{l}\text { - Pulse energy: } 250 \mathrm{~mJ} \\
\text { - Frequency: } 4 \mathrm{~Hz} \\
\text { - Non-contact mode } \\
\text { - Working distance: } \\
\text { 10mm }\end{array}$ & $\begin{array}{l}\text { - Carbide bur and Er:YAG } \\
\text { laser had a similar outcome } \\
\text { regarding caries removal } \\
\text { - Carisolv }{ }^{\oplus} \text { was less effective } \\
\text { than the carbide bur and the } \\
\text { Er:YAG laser and presented } \\
\text { remaining dentin with a lower } \\
\text { hardness compared to the } \\
\text { other methods } \\
\text { - There were no differences in } \\
\text { the calcium and phosphate } \\
\text { ratio among the three methods }\end{array}$ \\
\hline $\begin{array}{l}\text { Kornblit et } \\
\text { al. (2008) } \\
\text { [2] }\end{array}$ & $\begin{array}{l}30 \text { carious teeth } \\
\text { from children aged } \\
4 \text { to } 12 \mathrm{~s}\end{array}$ & Clinical trial & $\begin{array}{l}\text { - Possible } \\
\text { postoperative } \\
\text { complications after } \\
\text { caries removal with } \\
\text { the Er:YAG laser }\end{array}$ & $\begin{array}{l}\text { - Wavelength: } 2.94 \mu \mathrm{m} \\
\text { - Pulse duration: } 140 \mu \mathrm{s} \\
\text { - Pulse energy: } 120 \text { to } \\
200 \mathrm{~mJ} \\
\text { - Frequency: } 2 \text { to } 20 \mathrm{~Hz} \\
\text { - focus mode } \\
\text { - Working distance: } 0.8 \\
\text { to } 1 \mathrm{~cm}\end{array}$ & $\begin{array}{l}\text { - Children treated with Er:YAG } \\
\text { did not show any pain or } \\
\text { sensitivity } 7 \text { and } 28 \text { days after } \\
\text { the treatment }\end{array}$ \\
\hline $\begin{array}{l}\text { Krause et } \\
\text { al. (2008) } \\
{[15]}\end{array}$ & $\begin{array}{l}79 \text { carious lesions } \\
\text { from children aged } \\
3 \text { to } 12\end{array}$ & Clinical trial & $\begin{array}{l}\text { - Efficacy of the FCC } \\
\text { Er:YAG laser } \\
\text { - CFU count after } \\
\text { laser treatment } \\
\text { - Children } \\
\text { perceptions during } \\
\text { treatment }\end{array}$ & $\begin{array}{l}\text { - Wavelength: } 2.94 \mu \mathrm{m} \\
\text { - Pulse duration: } 400 \mu \mathrm{s} \\
\text { - Pulse energy: } 250 \mathrm{~mJ} \\
\text { - Frequency: } 4 \mathrm{~Hz} \\
\text { - non-contact mode } \\
\text { - Working distance: } \\
12 \mathrm{~cm} \\
\text { - Threshold: } 7 \mathrm{U}\end{array}$ & $\begin{array}{l}\text { - Treatment duration was } \\
2.3 \pm 1.2 \text { min } \\
-93.8 \% \text { of the children } \\
\text { considered the laser treatment } \\
\text { comfortable } \\
\text { - After laser ablation, } 42.9 \% \text { of } \\
\text { the samples showed residual } \\
\text { bacteria; however, only } 7.1 \% \\
\text { presented more than } 100 \mathrm{CFU} / \\
\text { sample }\end{array}$ \\
\hline $\begin{array}{l}\text { Li et al. } \\
\text { (2019) [32] }\end{array}$ & $\begin{array}{l}\text { Carious teeth from } \\
\text { children }\end{array}$ & $\begin{array}{l}\text { Meta- } \\
\text { analysis }\end{array}$ & $\begin{array}{l}\text { - Duration of } \\
\text { treatment } \\
\text { - Pain perception } \\
\text { - Success of } \\
\text { restorations }\end{array}$ & & $\begin{array}{l}\text { - Caries removal with laser is } \\
\text { more time consuming than the } \\
\text { use of bur } \\
\text { - the Er:YAG laser is less painful } \\
\text { than -the bur } \\
\text { - There were no statistical } \\
\text { differences in complete } \\
\text { restoration retention, marginal } \\
\text { discoloration, and marginal } \\
\text { adaptation between Er:YAG } \\
\text { laser and bur }\end{array}$ \\
\hline $\begin{array}{l}\text { Matsumoto } \\
\text { et al. (2007) } \\
{[36]}\end{array}$ & $\begin{array}{l}\text { Carious teeth from } \\
\text { adults }\end{array}$ & Clinical trial & $\begin{array}{l}\text { - Pain, discomfort, } \\
\text { assessment during } \\
\text { cavity preparation, } \\
\text { prognosis factor, } \\
\text { and overall clinical } \\
\text { evaluation }\end{array}$ & $\begin{array}{l}\text { - Wavelength: } 2.94 \mu \mathrm{m} \\
\text { - Pulse energy: } 700 \mathrm{~mJ} \\
\text { - Frequency: } 8 \mathrm{~Hz}\end{array}$ & $\begin{array}{l}\text { - Laser showed: low rate of } \\
\text { pain during treatment, no } \\
\text { discomfort, ample efficacy, } \\
\text { substantial efficiency, good } \\
\text { prognosis after three months } \\
\text { of follow-up, and mean of } \\
\text { treatment duration of } 49 \mathrm{~s}\end{array}$ \\
\hline $\begin{array}{l}\text { Medioni et } \\
\text { al. (2016) } \\
\text { [35] }\end{array}$ & $\begin{array}{l}\text { Carious molars } \\
\text { and premolars }\end{array}$ & $\begin{array}{l}\text { In vitro } \\
\text { comparative } \\
\text { study }\end{array}$ & $\begin{array}{l}\text { - Effectiveness of } \\
\text { - the Er:YAG laser, } \\
\text { carbide bur, and } \\
\text { polymer bur for } \\
\text { caries removal }\end{array}$ & $\begin{array}{l}\text { - Wavelength: } 2.94 \mu \mathrm{m} \\
\text { - Pulse energy: } 375 \mathrm{~mJ} \\
\text { - Pulse duration: } 50 \mu \mathrm{s} \\
\text { - Frequency: } 10 \mathrm{~Hz} \\
\text { - Quasi-contact mode }\end{array}$ & $\begin{array}{l}\text { - Procedure time was similar for } \\
\text { all the three methods } \\
\text { - Histological analysis showed } \\
\text { smear layer in the specimens } \\
\text { treated with carbide bur, } \\
\text { denatured collagen in the laser } \\
\text { group, and a layer of affected } \\
\text { dentin in the polymer bur } \\
\text { group } \\
\text { - All methods removed the } \\
\text { infected dentin }\end{array}$ \\
\hline $\begin{array}{l}\text { Neves et al. } \\
\text { (2011) [24] }\end{array}$ & Carious molarss & $\begin{array}{l}\text { In vitro } \\
\text { comparative } \\
\text { study }\end{array}$ & $\begin{array}{l}\text { - Influence of the } 7 \\
\text { methods for caries } \\
\text { removal in the } \\
\text { bonding capacity } \\
\text { of the remaining } \\
\text { dentin }\end{array}$ & $\begin{array}{l}\text { - Pulse energy: } 250 \mathrm{~mJ} \\
\text { - Pulse repetition rate: } \\
4 \text { pulses/s } \\
\text { - Non-contact mode } \\
\text { - Threshold: } 7 U\end{array}$ & $\begin{array}{l}\text { - Remaining denting from the } \\
\text { FCC Er:YAG laser group showed } \\
\text { lower } \mu \text { TBS values } \\
\text { - Carisolv showed the best } \\
\text { results regarding } \mu \text { TBS, } \\
\text { followed by carbide bur + caries } \\
\text { detector }\end{array}$ \\
\hline
\end{tabular}




\begin{tabular}{|c|c|c|c|c|c|}
\hline $\begin{array}{l}\text { Neves et al. } \\
\text { (2011) [18] }\end{array}$ & Carious molars & $\begin{array}{l}\text { In vitro } \\
\text { comparative } \\
\text { study }\end{array}$ & $\begin{array}{l}\text { - Caries removal } \\
\text { effectiveness and } \\
\text { minimally invasive } \\
\text { potential of } 9 \\
\text { methods for caries } \\
\text { removal by microCT }\end{array}$ & $\begin{array}{l}\text { - Pulse energy: } 250 \mathrm{~mJ} \\
\text { - Pulse repetition rate: } \\
4 \text { pulses/s } \\
\text { - Non-contact mode } \\
\text { - Threshold: } 7 U\end{array}$ & $\begin{array}{l}\text { - Chemomechanical methods } \\
\text { + metal excavators showed the } \\
\text { best results } \\
\text { - the FCC Er:YAG laser showed } \\
\text { the most variable results: } \\
\text { specimens with over and others } \\
\text { with under preparation } \\
\text { - the FCC Er:YAG laser did not } \\
\text { prove to be a selective method } \\
\text { for caries removal }\end{array}$ \\
\hline $\begin{array}{l}\text { Polizeli et al. } \\
\text { (2019) [29] }\end{array}$ & $\begin{array}{l}48 \text { primary } \\
\text { molars with } \\
\text { occlusal and } \\
\text { proximal caries } \\
\text { from children } \\
\text { aged } 7 \text { to } 10\end{array}$ & $\begin{array}{l}\text { Double- } \\
\text { blind, } \\
\text { randomized } \\
\text { clinical trial }\end{array}$ & $\begin{array}{l}\text { - Salivary cortisol } \\
\text { levels and clinical } \\
\text { performance of } \\
\text { restorations after } \\
\text { caries removal by } \\
\text { the Er:YAG laser } \\
\text { compared to } \\
\text { carbide bur }\end{array}$ & $\begin{array}{l}\text { - Medium short pulse } \\
\text { mode } \\
\text { - Pulse energy: } 250 \mathrm{~mJ} \\
\text { - Frequency: } 4 \mathrm{~Hz} \\
\text { - non-contact mode } \\
\text { - Working distance: } \\
7 \mathrm{~cm}\end{array}$ & $\begin{array}{l}\text { - Salivary cortisol levels were } \\
\text { similar for laser and bur } \\
\text { - There was no difference } \\
\text { regarding marginal adaptation, } \\
\text { retention, discoloration, } \\
\text { and secondary caries for } \\
\text { restorations from both groups } \\
\text { after one year of follow-up }\end{array}$ \\
\hline $\begin{array}{l}\text { Prabhakar et } \\
\text { al. (2018) [31] }\end{array}$ & $\begin{array}{l}\text { Carious primary } \\
\text { molars }\end{array}$ & $\begin{array}{l}\text { In vitro } \\
\text { comparative } \\
\text { study }\end{array}$ & $\begin{array}{l}\text { - Morphological } \\
\text { changes } \\
\text {-Bacterial deposits }\end{array}$ & $\begin{array}{l}\text { - Wavelength: } 2.94 \mu \mathrm{m} \\
\text { - Pulse energy: } 200 \mathrm{~mJ} \\
\text { - Energy density: } 22.5 \mathrm{~J} / \\
\mathrm{cm}^{2} \text { for } 10 \text { pulse/s } \\
\text { - Non-contact mode }\end{array}$ & $\begin{array}{l}\text { - the Er:YAG laser showed a } \\
\text { minor quantity of bacterial } \\
\text { deposits compared to } \\
\text { Carie-Carie and carbide bur; } \\
\text { Carie-Carie presented greatly } \\
\text { bacterial deposits } \\
\text { - Morphological changes: } \\
\text { Carbide bur - thin smear layer } \\
\text { and few open tubules; Er:YAG } \\
\text { laser: irregular rugged surface, } \\
\text { no smear layer, opened tubules; } \\
\text { Carie-Carie - rough surface, } \\
\text { smear layer, obliterated tubules }\end{array}$ \\
\hline $\begin{array}{l}\text { Sattabanasuk } \\
\text { et al. (2006) } \\
{[25]}\end{array}$ & $\begin{array}{l}\text { Carious third } \\
\text { molars }\end{array}$ & $\begin{array}{l}\text { In vitro } \\
\text { comparative } \\
\text { study }\end{array}$ & $\begin{array}{l}\text { - Influence of } 3 \\
\text { methods for caries } \\
\text { removal and two } \\
\text { types of adhesive } \\
\text { systems in the } \\
\text { bonding capacity } \\
\text { of the remaining } \\
\text { dentin }\end{array}$ & $\begin{array}{l}\text { - Pulse energy: } 180 \mathrm{~mJ} \\
\text { - Frequency: } 2 \mathrm{~Hz} \\
\text { - Non-contact mode }\end{array}$ & $\begin{array}{l}\text { - The total-etch adhesive } \\
\text { system (OptiBond Solo Plus) } \\
\text { showed similar results in all } \\
\text { groups (steel bur, laser, and SiC } \\
\text { paper) } \\
\text { - The self-etch adhesive system } \\
\text { (Clearfil Protect Bond) showed } \\
\text { lower bond strength in dentin } \\
\text { treated with steel bur } \\
\text {-Only the laser group showed } \\
\text { similar bond strength for the } \\
\text { two tested adhesive systems }\end{array}$ \\
\hline $\begin{array}{l}\text { Schwass et al. } \\
\text { (2013) [20] }\end{array}$ & $\begin{array}{l}\text { Teeth with } \\
\text { proximal dentin } \\
\text { caries }\end{array}$ & $\begin{array}{l}\text { In vitro } \\
\text { comparative } \\
\text { study }\end{array}$ & $\begin{array}{l}\text { - Different } \\
\text { thresholds of } \\
\text { FCC Er:YAG in the } \\
\text { selectivity of caries } \\
\text { removal }\end{array}$ & $\begin{array}{l}\text { - Pulse energy: } 600 \mathrm{~mJ} \\
\text { (enamel) and } 250 \mathrm{~mJ} \\
\text { (dentin) } \\
\text { - Frequency: } 10 \mathrm{~Hz} \\
\text { (enamel) and } 4 \mathrm{~Hz} \\
\text { (dentin) } \\
\text { - Pulse duration: } 400 \mu \mathrm{s} \\
\text { - Threshold: } 4,5,6,7,8 \text {, } \\
9,10,12,16, \text { and } 20 \mathrm{U} \\
\text { - Non-contact mode }\end{array}$ & $\begin{array}{l}\text { - Feedback control values } \\
\text { higher than } 8 U \text { did not remove } \\
\text { infected caries efficiently } \\
\text { - Threshold for conservative } \\
\text { caries removal lies between } 7 \\
\text { and } 8 U\end{array}$ \\
\hline $\begin{array}{l}\text { Sirin } \\
\text { Karaarslan et } \\
\text { al. (2012) [26] }\end{array}$ & Carious molars & $\begin{array}{l}\text { In vitro } \\
\text { comparative } \\
\text { study }\end{array}$ & $\begin{array}{l}\text { - Influence of } 3 \\
\text { methods for caries } \\
\text { removal and three } \\
\text { adhesive systems } \\
\text { in the bonding } \\
\text { capacity of the } \\
\text { remaining dentin }\end{array}$ & $\begin{array}{l}\text { - Wavelength: } 2.94 \mu \mathrm{m} \\
\text { - Power output: } 3.5 \mathrm{~W} \\
\text { - Pulse duration: } 300 \mu \mathrm{s} \\
\text { (short pulse mode) } \\
\text { - Frequency: } 10 \mathrm{~Hz} \\
\text { - 1mm distance } \\
\text { - Energy density: } 44 \mathrm{~J} / \\
\mathrm{cm}^{2}\end{array}$ & $\begin{array}{l}\text { - The total-etch adhesive } \\
\text { system: similar bond strength } \\
\text { values for steel bur and laser } \\
\text { and lower for Carisolv } \\
\text { - One-step and two-step self- } \\
\text { etch adhesive systems: similar } \\
\text { bond strength values for all } \\
\text { three methods } \\
\text { - the bur group: all adhesive } \\
\text { systems had the same behavior } \\
\text { - the laser group: total-etch } \\
\text { adhesive showed the higher } \\
\mu \text { TBS values } \\
\text {-Carisolv }{ }^{\circledast} \text { : two-step self-etch } \\
\text { adhesive showed the best } \\
\text { results }\end{array}$ \\
\hline
\end{tabular}




\begin{tabular}{|c|c|c|c|c|c|}
\hline $\begin{array}{l}\text { Tsanova } \\
\text { \& Tomov } \\
\text { (2010) [22] }\end{array}$ & $\begin{array}{l}\text { Carious teeth } \\
\text { from adults }\end{array}$ & $\begin{array}{l}\text { In vitro } \\
\text { comparative } \\
\text { study }\end{array}$ & $\begin{array}{l}\text { - Ultrastructural } \\
\text { changes in substrates } \\
\text { treated with Er:YAG } \\
\text { laser, Carisolv }^{\circledR} \\
\text { diamond bur, steel } \\
\text { bur }\end{array}$ & $\begin{array}{l}\text { - Pulse energy: } 400 \mathrm{~mJ} \\
\text { - Frequency: } 20 \mathrm{~Hz} \\
\text { - Power output: } 8 \mathrm{~W}\end{array}$ & $\begin{array}{l}\text { - Er:YAG laser: irregular and } \\
\text { rough dentin surface with no } \\
\text { smear layer, exposed tubules; } \\
\text { retentive enamel } \\
\text { - Carisolv }: \text { dentin with rough } \\
\text { and granular aspect, retentive } \\
\text { surface } \\
\text { The diamond bur: thin and } \\
\text { smooth smear layer in most } \\
\text { regions and absence in a few } \\
\text { others, opened tubules } \\
\text { The steel bur: smear layer and } \\
\text { obliterated tubules }\end{array}$ \\
\hline $\begin{array}{l}\text { Valério et } \\
\text { al. (2016) } \\
\text { [8] }\end{array}$ & $\begin{array}{l}\text { Carious } \\
\text { primary } \\
\text { molars from } \\
\text { children aged } \\
6 \text { to } 10\end{array}$ & $\begin{array}{l}\text { Split-mouth } \\
\text { randomized } \\
\text { clinical trial }\end{array}$ & $\begin{array}{l}\text { - Er:YAG laser } \\
\text { effectiveness } \\
\text { compared to carbide } \\
\text { bur } \\
\text { - CFU count } \\
\text { - Restoration } \\
\text { longevity }\end{array}$ & $\begin{array}{l}\text { - Pulse energy: } 250 \mathrm{~mJ} \\
\text { - Frequency: } 4 \mathrm{~Hz} \\
\text { - Non-contact mode } \\
\text { - } 7 \mathrm{~mm} \text { distance } \\
\text { - Energy density: } 39 \mathrm{~J} / \mathrm{cm}^{2}\end{array}$ & $\begin{array}{l}\text { - The carbide bur is faster and } \\
\text { more effective to remove caries } \\
\text { in the surrounding walls than } \\
\text { Er:YAG laser } \\
\text { - CFU for S. mutans and } \\
\text { Lactobacilli sp. was similar for } \\
\text { both methods } \\
\text { - One-year follow-up showed } \\
\text { no differences in restoration } \\
\text { longevity for both groups }\end{array}$ \\
\hline $\begin{array}{l}\text { Valério et } \\
\text { al. (2020) } \\
{[30]}\end{array}$ & $\begin{array}{l}\text { Carious } \\
\text { molars from } \\
\text { children aged } \\
8 \text { to } 12\end{array}$ & $\begin{array}{l}\text { Longitudinal } \\
\text { clinical trial }\end{array}$ & $\begin{array}{l}\text { - Influence of Er:YAG } \\
\text { and carbide bur } \\
\text { associated with } \\
\text { chlorhexidine at the } \\
\text { longevity of adhesive } \\
\text { restorations after four } \\
\text { years of follow-up }\end{array}$ & $\begin{array}{l}\text { - Medium short pulse } \\
\text { mode } \\
\text { - Pulse energy: } 260 \mathrm{~mJ} \\
\text { - Frequency: } 4 \mathrm{~Hz} \\
\text { - Non-contact mode } \\
\text {-12mm distance } \\
\text { - Energy density: } 41 \mathrm{~J} / \mathrm{cm}^{2}\end{array}$ & $\begin{array}{l}\text { - The clinical longevity of the } \\
\text { restorations was affected } \\
\text { neither by the method for } \\
\text { caries removal nor by the } \\
\text { dentin biomodification with } \\
\text { chlorhexidine at four years of } \\
\text { follow-up }\end{array}$ \\
\hline $\begin{array}{l}\text { Yan et al. } \\
\text { (2015) [19] }\end{array}$ & $\begin{array}{l}\text { Teeth with } \\
\text { occlusal caries }\end{array}$ & In vitro study & $\begin{array}{l}\text { - Potential of a diode } \\
\text { pumped solid-state } \\
\text { (DPSS) Er:YAG laser for } \\
\text { caries removal }\end{array}$ & $\begin{array}{l}\text { - Pulse duration: } 20-30 \mu \mathrm{s} \\
\text { - Frequency: } 500 \mathrm{~Hz} \\
\text { - Power output: } 30 \mathrm{~W}\end{array}$ & $\begin{array}{l}\text { - Ablation with minor thermal } \\
\text { damage } \\
\text { - Higher ablation rate in } \\
\text { demineralized surfaces } \\
\text { compared to the sound ones }\end{array}$ \\
\hline $\begin{array}{l}\text { Yildiz et al. } \\
\text { (2013) [27] }\end{array}$ & $\begin{array}{l}\text { Carious } \\
\text { primary molar } \\
\text { teeth }\end{array}$ & $\begin{array}{l}\text { In vitro } \\
\text { comparative } \\
\text { study }\end{array}$ & $\begin{array}{l}\text { - Influence of } 3 \\
\text { methods for caries } \\
\text { removal and two } \\
\text { adhesive systems in } \\
\text { the bonding capacity } \\
\text { of the remaining } \\
\text { dentin }\end{array}$ & $\begin{array}{l}\text { - Wavelength: } 2.94 \mu \mathrm{m} \\
\text { - Power output: } 3.5 \mathrm{~W} \\
\text { - Pulse duration: } 300 \mu \mathrm{s} \\
\text { (short pulse mode) } \\
\text { - Frequency: } 10 \mathrm{~Hz} \\
\text { - 1mm distance } \\
\text { - Energy density: } 44 \mathrm{~J} / \mathrm{cm}^{2}\end{array}$ & $\begin{array}{l}\text { - Laser presented lower } \mu \text { TBS } \\
\text { values than carbide bur and } \\
\text { Carisolv } v^{\circledR} \text { groups regardless of } \\
\text { the adhesive system used } \\
\text { (one-step self-etch and two- } \\
\text { step total-etch) } \\
\text { - Bur and Carisolv }{ }^{\circledR} \text { presented } \\
\text { the best results for both types } \\
\text { of adhesive systems }\end{array}$ \\
\hline $\begin{array}{l}\text { Yonemoto } \\
\text { et al. (2006) } \\
\text { [21] }\end{array}$ & $\begin{array}{l}\text { Molars with } \\
\text { occlusal } \\
\text { dentin caries }\end{array}$ & In vitro study & $\begin{array}{l}\text { - Values of } \\
\text { DIAGNOdent }{ }^{\oplus} \text { that } \\
\text { could be used as a } \\
\text { guide for the removal } \\
\text { of the outer layer of } \\
\text { carious dentin with } \\
\text { Er:YAG laser }\end{array}$ & $\begin{array}{l}\text { - Pulse energy: } 150-200 \mathrm{~mJ} \\
\text { (enamel) and } 50-150 \mathrm{~mJ} \\
\text { (dentin) } \\
\text { - Pulse duration: } 200 \mu \mathrm{s} \\
\text { Frequency: } 10,20,25 \text { or } \\
30 \mathrm{~Hz}\end{array}$ & 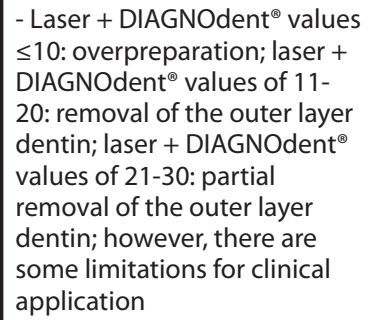 \\
\hline
\end{tabular}

Table 1. Summary of the selected articles.

\section{CONCLUSION}

The Er:YAG laser is a viable alternative for the treatment of caries since it can remove demineralized tissue without causing damage to the dental element, in addition to providing greater comfort for the patient due to the absence of noise, vibrations, and pressures during removal of decayed tissue and less need for anesthetic administration in most cases.

\section{REFERENCES}

1. Jepsen S, Acil Y, Peschel T, et al. Biochemical and morphological analysis of dentin following selective caries removal with a fluorescence-controlled Er:YAG laser. Lasers Surg Med. 2008 Jul;40(5):350-357. doi: 10.1002/lsm.20631. PMID: 18563782 CrossRef PubMed Google Scholar Scopus WoS
Despite the advantages, its use requires more clinical time compared to the use of burs. Furthermore, the cost of the equipment, despite not having been addressed in the review, can also be considered a limiting factor. In general, the Er:YAG laser is as effective as the conventional and chemicalmechanical methods for selective caries removal.

\section{ACKNOWLEDGMENTS}

None.

2. Kornblit R, Trapani D, Bossù M, et al. The use of Erbium:YAG laser for caries removal in paediatric patients following Minimally Invasive Dentistry concepts. Eur J Paediatr Dent. 2008 Jun;9(2):81-87. PMID: 18605890.

Full text link PubMed Google Scholar Scopus WoS 
3. Parker S, Cronshaw M, Anagnostaki E, et al. Current concepts of laser-oral tissue interaction. Dent J (Basel). 2020 Jun 28;8(3):61. doi: 10.3390/dj8030061. PMID: 32605215; PMCID: PMC7558496.2020;8(3):61.

CrossRef PubMed Google Scholar Scopus WoS

4. Jorge ACT, Cassoni A, Rodrigues JA. [Applications of highintensity lasers in dentistry]. Portuguese. Rev Saúde - UNG.

2010;4(3):25-33.

Full text link Google Scholar

5. Neves LS, Silva CMS, Henriques JFC, et al. [The use of laser in orthodontics]. Portuguese. Rev Dent Press Orthodon Orthoped Facial. 2005;10(5):149-156. https://doi.org/10.1590/S141554192005000500015

CrossRef Google Scholar

6. Convissar RA. Principles and Practice of Laser Dentistry. 2nd Edition. St Louis, Ml: Elsevier; 2016. ISBN: 9780323297622

7. Al-Batayneh OB, Seow WK, Walsh LJ. Assessment of Er:YAG laser for cavity preparation in primary and permanent teeth: a scanning electron microscopy and thermographic study. Pediatr Dent. 2014 May-Jun;36(3):90-94. PMID: 24960377.

Full text link PubMed Google Scholar Scopus

8. Valério RA, Borsatto MC, Serra MC, et al. Caries removal in deciduous teeth using an Er:YAG laser: a randomized split-mouth clinical trial. Clin Oral Investig. 2016 Jan;20(1):65-73. doi: 10.1007/ s00784-015-1470-z. Epub 2015 Apr 17. PMID: 25877234. CrossRef PubMed Google Scholar Scopus WoS

9. Maltz M. [Cariology: Basic Concepts, Diagnosis and NonRestorative Treatment]. Portuguese. São Paulo: Artes Médicas; 2016. ISBN: 978-8536702629.

10. Baratieri LN, Júnior SM. [Restorative Dentistry - Fundamentals and Possibilities]. 2nd Edition. Portuguese. São Paulo: Santos; 2015. ISBN: 978-8541203173

11. Kavvadia K, Karagianni V, Polychronopoulou A, Papagiannouli L. Primary teeth caries removal using the Carisolv chemomechanical method: a clinical trial. Pediatr Dent. 2004 Jan-Feb;26(1):23-8. PMID: 15080354.

Full text link PubMed Google Scholar Scopus WoS

12. Kotb RMS, Abdella AA, El Kateb MA, Ahmed AM. Clinical evaluation of Papacarie in primary teeth. J Clin Pediatr Dent. 2009 Winter;34(2):117-123. doi: 10.17796/

jcpd.34.2.f312p36g18463716. PMID: 20297701

CrossRef PubMed Google Scholar Scopus WoS

13. Bohari MR, Chunawalla YK, Ahmed BMN. Clinical

evaluation of caries removal in primary teethusing

conventional, chemomechanical and laser technique: an in vivo

study. J Contemp Dent Pract. 2012 Jan 1;13(1):40-47. doi: 10.5005/ jp-journals-10024-1093. PMID: 22430692.

CrossRef PubMed Google Scholar

14. Cozean C, Arcoria CJ, Pelagalli J, Powell GL. Dentistry for the 21st century? Erbium:YAG laser for teeth. J Am Dent Assoc. 1997 Aug;128(8):1080-1087. doi: 10.14219/jada.archive.1997.0364. PMID: 9260417.

CrossRef PubMed Google Scholar

15. Krause F, Braun A, Lotz G, et al. Evaluation of selective caries re moval in deciduous teeth by a fluorescence feedback-controlled

Er:YAG laser in vivo. Clin Oral Investig. 2008 Sep;12(3):209-215. doi: 10.1007/s00784-007-0169-1. Epub 2008 Jan 26. PMID: 18224360. CrossRef PubMed Google Scholar Scopus WoS

16. Eberhard J, Bode K, Hedderich J, Jepsen S. Cavity size difference after caries removal by a fluorescence-controlled Er:YAG laser and by conventional bur treatment. Clin Oral Investig. 2008 Sep;12(3):209-215. doi: 10.1007/s00784-007-0169-1. Epub 2008 Jan 26. PMID: 18224360.

CrossRef PubMed Google Scholar Scopus WoS

17. Dommisch H, Peus K, Kneist S, et al. Fluorescence-controlled Er:YAG laser for caries removal in permanent teeth: a randomized clinical trial. Eur J Oral Sci. 2008 Apr;116(2):170-176. doi: 10.1111/j.1600-0722.2008.00521.x. PMID: 18353012. CrossRef PubMed Google Scholar Scopus WoS

18. Neves AA, Coutinho E, De Munck J, Van Meerbeek B. Cariesremoval effectiveness and minimal-invasiveness potential of caries-excavation techniques: a micro-CT investigation. J Dent. 2011 Feb;39(2):154-162. doi: 10.1016/j.jdent.2010.11.006. Epub 2010 Nov 25. PMID: 21111770.

CrossRef PubMed Google Scholar Scopus WoS

19. Yan $\mathrm{R}$, Chan $\mathrm{KH}$, Tom $\mathrm{H}$, et al. Selective removal of dental caries with a diode-pumped Er:YAG laser. Proc SPIE Int Soc Opt Eng. 2015 Feb 24;9306:930600. doi: 10.1117/12.2083653. PMID: 25914496; PMCID: PMC4405669.

CrossRef PubMed Google Scholar Scopus WoS

20. Schwass DR, Leichter JW, Purton DG, Swain MV. Evaluating the efficiency of caries removal using an Er: YAG laser driven by fluorescence feedback control. Arch Oral Biol. 2013 Jun;58(6):603610. doi: 10.1016/j.archoralbio.2012.09.017. Epub 2012 Nov 1. PMID: 23123070.

CrossRef PubMed Google Scholar Scopus WoS
21. Yonemoto K, Eguro T, Maeda T, Tanaka H. Application of DIAGNOdent ${ }^{\circledR}$ as a guide for removing carious dentin with Er:YAG laser. J Dent. 2006 Apr;34(4):269-76. doi: 10.1016/j.jdent.2005.07.001. Epub 2005 Sep 8. PMID: 16153765.

CrossRef PubMed Google Scholar Scopus WoS

22. Tsanova S, Tomov G. Morphological changes in hard dental tissues prepared by Er:YAG laser (LiteTouch, Syneron), Carisolv and rotary instruments. A scanning electron microscopy evaluation. Folia Med. (Plovdiv). 2010 Jul-Sep;52(3):46-55. doi: 10.2478/v10153-010-0006-1. PMID: 21053673. CrossRef PubMed Google Scholar

23. Juntavee A, Juntavee N, Peerapattana J, et al. Comparison of marginal microleakage of glass ionomer restorations in primary molars prepared by chemo-mechanical caries removal (CMCR), Erbium:Yttrium Aluminum-Garnet (Er:YAG) laser and atraumatic restorative technique (ART). Int J Clin Pediatr Dent. 2013;6(2):75-79. doi: 10.5005/jp-journals-10005-1193. Epub 2013 Aug 26. PMID: 25206196; PMCID: PMC4086587.

CrossRef PubMed Google Scholar

24. Neves AA, Coutinho E, Cardoso MV, et al. Micro-tensile bond strength and interfacial characterization of an adhesive bonded to dentin prepared by contemporary caries-excavation

techniques. Dent Mater. 2011 Jun;27(6):552-562. doi: 10.1016/j.dental.2011.02.008. Epub 2011 Apr 13. PMID: 21489617

CrossRef PubMed Google Scholar Scopus WoS

25. Sattabanasuk V, Burrow M, Shimada Y, Tagami J. Resin

adhesion to caries-affected dentine after different removal methods. Aust Dent J. 2006 Jun;51(2):162-9. doi: 10.1111/j.1834-7819.2006. tb00421.x. PMID: 16848265 .

CrossRef PubMed Google Scholar Scopus WoS

26. Sirin Karaarslan E, Yildiz E, Cebe M, et al. Evaluation of

micro-tensile bond strength of caries-affected human dentine

after three different caries removal techniques. J Dent. 2012

Oct:40(10):793-801. doi: 10.1016/j.jdent.2012.05.013. Epub 2012 Jun 9. PMID: 22687577.

CrossRef PubMed Google Scholar Scopus WoS

27. Yildiz E, Sirin Karaarslan E, Yegin Z, et al. Effect of caries removal

techniques on the bond strength of adhesives to caries-affected primary dentin in vitro. Eur J Paediatr Dent. 2013 Sep;14(3):209-214 PMID: 24295006.

Full text link PubMed Google Scholar Scopus WoS

28. Katirci G, Ermis RB. Microindentation hardness and calcium phosphorus ratio of dentin following excavation of dental caries lesions with different techniques. Springerplus. 2016 Sep 22.5(1):1641 doi: 10.1186/s40064-016-3289-8. PMID: 27722059.

PMCID: PMC5031566.

CrossRef PubMed Google Scholar Scopus WoS

29. Polizeli SAF, Curylofo-Zotti FA, Valerio RA, et al. Selective removal of necrotic dentin in primary teeth using laser irradiation: one-year clinical evaluation of composite restorations. J Lasers Med Sci. 2019 Spring;10(2):108-116. doi: 10.15171/jlms.2019.18. Epub 2019 Feb 25. PMID: 31360379; PMCID: PMC6499567.

CrossRef PubMed Google Scholar

30. Valério RA, Galo R, Galafassi D, et al. Four-year clinical prospective follow-up of resin composite restoration after selective caries removal using Er:YAG laser. Clin Oral Investig. 2020 Jul; 24(7):22712283. doi: 10.1007/s00784-019-03082-w. Epub 2019 Nov 4. PMID: 31686235.

CrossRef PubMed Google Scholar

31. Prabhakar A, Lokeshwari M, Naik SV, Yavagal C. Efficacy of caries removal by Carie-Care and Erbium-doped Yttrium Aluminum Garnet laser in primary molars: a scanning electron microscope study. Int J Clin Pediatr Dent. 2018 Jul-Aug;11(4):323-329. doi: 10.5005/jp-journals-10005-1533. Epub 2018 Aug 1. PMID: 30397377; PMCID: PMC6212662.

CrossRef PubMed Google Scholar

32. Li T, Zhang X, Shi H, et al. Er:YAG laser application in caries removal and cavity preparation in children: a meta-analysis. Lasers Med Sci. 2019 Mar;34(2):273-280. doi: 10.1007/s10103-018-2582-x. Epub 2018 Jul 12. PMID: 30003427

CrossRef PubMed Google Scholar Scopus WoS 33. Cardoso M, Coelho A, Lima R, et al. Efficacy and patient's acceptance of alternative methods for caries removal - a systematic review. J Clin Med. 2020 Oct 23;9(11):3407. doi: 10.3390/jcm9113407. PMID: 33114249; PMCID: PMC7690910.

CrossRef PubMed Google Scholar Scopus WoS

34. Baraba A, Kqiku L, Gabric D, et al. Efficacy of removal of cariogenic bacteria and carious dentin by ablation using different modes of Er:YAG lasers. Braz J Med Biol Res. 2018 Jan 11;51(3):e6872. doi: 10.1590/1414-431X20176872. PMID: 29340524; PMCID: PMC5769758.

CrossRef PubMed Google Scholar Scopus WoS

35. Medioni E, Rocca JP, Fornaini C, Merigo E. Histological evaluation of three techniques for caries removal. J Oral Sci. 2016;58(4):583-589. doi: 10.2334/josnusd.16-0225. PMID: 28025444.

CrossRef PubMed Google Scholar 
36. Matsumoto K, Wang X, Zhang C, Kinoshita J. Effect of a novel Er:YAG laser in caries removal and cavity preparation: a clinical observation. Photomed Laser Surg. 2007 Feb;25(1):8-13. doi: 10.1089/ pho.2006.2020. PMID: 17352631.

CrossRef PubMed Google Scholar

37. Celiberti P, Francescut P, Lussi A. Performance of four dentine excavation methods in deciduous teeth. Caries Res. 2006;40(2):117

123. doi: 10.1159/000091057. PMID: 16508268.

CrossRef PubMed Google Scholar Scopus WoS
38. Cebe F, Bulbul M, Simsek I, et al. Effect of Erbium: yttrium aluminum garnet laser on bond strength of a total-etch adhesive system to caries-affected dentin on gingival wall. Niger J Clin Pract. 2017 Jun;20(6):734-740. doi: 10.4103/1119-3077.181321. PMID: 28656929. CrossRef PubMed Google Scholar Scopus WoS

39. Zach L, Cohen G. Pulp response to externally applied heat. Oral Surg Oral Med Oral Pathol. 1965 Apr;19:515-530. doi: 10.1016/00304220(65)90015-0. PMID: 14263662.

CrossRef PubMed Google Scholar Scopus

\section{Geise dos Santos MARCELINO}

DDS, General Dentist

Department of Restorative Dentistry

School of Dentistry

Faculdade Morgana Potrich (FAMP)

Mineiros, Goiás, Brazi

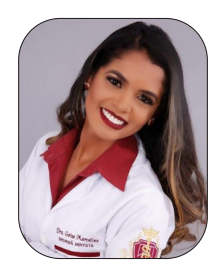

Geise dos Santos Marcelino graduated from FAMP, Mineiros, Goiás, Brazil, and is a student of the Specialization course in Orthodontics at the Graduate Center in Dentistry - CIOG, Goiânia, Goiás. Her academic interests include Hospital Dentistry and Pediatric Dentistry. She works as a general dentist in a private practice in Senador Canedo, Goiás and at the PSF in Taquaral de Goiás, Goiás, Brazil.

\section{Ouestions}

\section{Which caries removal method is the least conservative?}

a. Mechanical removal with dentin scoop;

ab. Diamond tips and air rotor;

ac. Er:YAG laser;

d. Use of a chemical-mechanical method.

\section{Which is the Er:YAG laser wavelength?}

口a. 2.940nm;

ab. $2.840 \mathrm{~nm}$;

口c. $2.490 \mathrm{~nm}$;

ad. $2.480 \mathrm{~nm}$

\section{Which sentence is correct?}

口a. Er:YAG is a selective method for caries removal;

$\square$ b. Chemical-mechanical methods cause more pain for the patients;

口. Er:YAG can affect pulp vitality;

$\square d$. Carbide burs cannot be used in children.

\section{In dentistry, which one is the most desirable phenomenon of the laser?}

a. Diffusion;

b. Transmission;

ac. Absorption;

ad. Penetration. 